\title{
Study of Low-Fat Ice Cream with The Substitution of Super Red Dragon (Hylocereus costaricensis) Fruit Peel
}

\author{
Sahrial Hafids", Silvi Leila Rahmi*, Annida Rani Chairunisah* \\ \#Department of Agroindustrial Technology, Faculty of Agricultural Engineering and Technology, Jambi University, \\ *Department of Agricultural Product Technology, Faculty of Agricultural Engineering and Technology, Jambi University, \\ Jl. Tri Brata KM 11, Pondok Meja, Mestong, Muaro Jambi 36364, Indonesia \\ E-mail:sahrial@unja.ac.id
}

\begin{abstract}
This research aimed to identify the effect of the substitution of super red dragon fruit peel (Hylocereus costaricensis) towards the physical and organoleptic characteristic of low-fat ice cream, to determine the best formulation of the Substitution of super red dragon fruit peel (Hylocereus costaricensis) into low-fat ice cream and to determine whether the best formulation of low-fat ice cream with the substitution of super red dragon fruit peel (Hylocereus costaricensis) is as acceptable as commercial ice cream. This research was designed using a completely randomized design (CRD) with the substitution of super red dragon fruit peel $(0,6,8,10$, and $12 \%$ w/w) as the treatments. The parameters of overrun, melting time, viscosity, colour ( $L^{*}$, $a^{*}$ and $b^{*}$ values), and organoleptic evaluation including hedonic quality of colour and texture and overall acceptance were analyzed. The best treatment of organoleptic evaluation then was analyzed by paired comparison evaluation method with commercial ice cream. The result showed that the substitution of super red dragon fruit peel was significantly different $(P<0,01)$ on overrun, melting time, viscosity, colour $\left(L^{*}, a^{*}\right.$ and $b^{*}$ values), hedonic quality of colour and texture, and overall acceptance. The substitution of $8 \%$ super red dragon fruit peel was found to be the best treatment based on organoleptic evaluation with overrun of $38,40 \%$, melting time of 16,11 minutes, viscosity of $551,03 \mathrm{cP}$, colour; $L^{*} 63,80, a^{*} 12,78, b^{*} 19,25$, hedonic quality of colour 3,10 (pink), texture 4,15 (smooth, non-snowy) and overall acceptance 4,45 (like moderately). The best formulation of low-fat ice cream with the substitution of $8 \%$ super red dragon fruit peel was not significantly different on the paired comparison evaluation with the score of 0,20 (Similar).
\end{abstract}

Keywords - Ice cream; Low-fat; Peel; Super Red Dragon Fruit.

\section{INTRODUCTION}

Nowadays, consumers have become more interested in low-calories products since they associate low-calories products with a reduced risk of coronary heart diseases [1]. This behavior has incited the development of healthy products.

Healthy products must have at least one of the following characteristics: a modified composition to prevent or limit the presence of potentially harmful compounds, such as fat, and or the possibility of adding certain substances, such as fiber, with additional health benefits [2].

Ice cream is a complex colloidal frozen system composed of partially coalesced fat droplets, air cells, ice crystals, and a continuous aqueous in which the polysaccharides, protein, lactose, and mineral salts are dispersed [2].

Low-fat ice cream contains about 2-4\% milk fat, while conventional ice cream formulation has a high fat content, it is about 10 to $16 \%$ [3]. Low-fat ice cream has special attraction for people who desire low-fat diet. Most people avoid the fat since it can lead to overweight or obesity. People are increasingly aware that obesity can results various diseases. The Food and Drug Administration (FDA) has approved the use of labeling names of reduced-fat, lowfat and non-fat ice creams for such products that containing less than $10 \%$ milk fat [1].

The fat in ice cream can be partially replaced with low calorie nutrients such as protein or carbohydrates [4]. Dietary fibers can be used as fat replacers in low fat ice cream manufacturers. Fat replacers are used in fat-free and low-fat ice cream [5].

Carbohydrate-based fat replacers have been used in products as potential fat replacers. The carbohydrate-based fat replacer has the ability to form gel, to increase viscosity, to provide texture and mouthfeel, and to increase waterholding capacity [2]. The substitution of dietary fiber in variety of foods will contribute the value-added or the functional value in foods which will impact a high demand by consumers.

According to $\mathrm{Wu}$ et al. [6], dragon fruit peel is an agricultural waste in the fruit juice processing industry that is currently only used as a fertilizer. However, various studies have shown that dragon fruit peel is a potential source of natural functional food ingredients. According to Saneto [7], red dragon fruit peels are a good source of dietary fibers and are potential to be developed as a novel source of dietary fibers. One of active ingredient found in 
dragon fruit peel is betalain. Betalain is a compound which contribute the colour of some fruits and it is also improve the health. Red dragon fruit peel fulfill the criteria as a natural dies and fat replacer in ice cream manufatures, thereby dispel the bad hesitation of the use of artificial colouring for the health [8].

This research aimed to identify the effect of the substitution of super red dragon fruit peel (Hylocereus costaricensis) towards the physical and organoleptic characteristic of low-fat ice cream and to determine the best formulation of the substitution of super red dragon fruit peel (Hylocereus costaricensis) into low-fat ice cream.

\section{THE MATERIAL AND METHOD}

This research carried out on May-August 2017 in Laboratory of Analysis and Processing of Agricultural Product, Faculty of Agricultural Technology, University of Jambi. Materials used in the ice cream processing i.e. super red dragon fruit peel (Hylocereus costaricensis), full cream milk powder, skim milk powder, sucrose, corn syrup solids, Tween 80, CMC and $\kappa$-karagenan. Equipments used in this research i.e. moisture balance, blender, mixer, analytical balance, freezer, refrigerator, thermometer, falling-ball viscometer, colour reader (CR-10, Konica Minolta), measuring cylinder, volumetric flask, dropper, petri disk, watch glass, stirring rod, filter paper, stopwatch.

This research was performed in a Completely Randomized Design (CRD) with the treatment of the substitution of super red dragon fruit peel to make the total of 500 grams low-fat ice cream with the substitution of super red dragon fruit peel (Hylocereus costaricensis) with 5 treatments $(0,6,8,10$, dan $12 \% \mathrm{w} / \mathrm{w})$ and performed in 4 replicates obtained 20 units of experiments.

Overrun [5], Melting time [9], Viscosity [10], Colour; L* $a^{*} b^{*}[11]$ and organoleptic evaluation [12] were analyzed. The best treatment of organoleptic evaluation then was analyzed by paired comparison evaluation method with commercial ice cream.

\section{A. Moisture Content Determination of Super Red Dragon Fruit Peel}

Moisture content of super red dragon fruit peel was determined using Moisture Balance. 5 grams of sample was heated with moisture balance with the temperature of $160^{\circ} \mathrm{C}$. The water content of sample is displayed on the monitor after 20-30 minutes.

\section{B. Processing of Super Red Dragon Fruit Peel Puree [13]}

Cleaned dragon fruit peel is separated from the fruit pulp with stainless steel knife then being sortated. Then, the peel is mashed into dragon fruit peel puree using blender by adding water.

\section{Low-Fat Ice Cream Formulations [5]}

Low-fat ice cream are formulated from $4 \%$ milk fat, $15,5 \%$ milk solids-non-fat, $12 \%$ sucrose, $3 \%$ corn syrup solids, $0,1 \%$ tween $80,0,1 \% \kappa-$ carrageenan, $0,25 \% \mathrm{CMC}$ and $65,05 \%$ water.

\section{Processing of Low-Fat Ice Cream with The Substitution of Super Red Dragon Fruit Peel [14]}

Each of the treatments of low-fat ice cream with the substitution of super red dragon fruit peel is formulated. The mixes are stirred well until even. The mixes are then pasteurized at $90^{\circ} \mathrm{C}$ for $3 \mathrm{sec}$. Then, the mixes are homogenized for $15 \mathrm{~min}$ using mixer (1130 rpm) on a stainless steel bowl which is surrounded by ice cubes. The mixes are being ageing in refrigerator for $24 \mathrm{hr}$ at $4^{\circ} \mathrm{C}$, then the mixes are whipped using mixer $(800 \mathrm{rpm})$ for $15 \mathrm{~min}$. Then, the mixes are hardened in freezer at $-20^{\circ} \mathrm{C}$ to $-50^{\circ} \mathrm{C}$.

\section{RESULTS AND DISCUSSION}

The result showed that the substitution of super red dragon fruit peel is significantly different $(\mathrm{P}<0,01)$ on overrun, melting time, viscosity, colour $\left(\mathrm{L}^{*}, \mathrm{a}^{*}\right.$ and $\mathrm{b}^{*}$ values), hedonic quality of colour and texture, and overall acceptance, but not different significantly on paired comparison evaluation.

In this research the peel of super red dragon fruit which was used has the water content of 93,3-96,4\%. According to Khalili et al. [15], red dragon fruit peel contained 263,86 $\mu \mathrm{g} / 100 \mathrm{gr}$ prebiotic oligosaccharides including; raffinose, stachyose, maltotri-ose, maltotetriose, maltopentaose, maltohexaose, maltoheptaose and fructo-oligosaccharides. Thereby, low-fat ice cream with the substitution of super red dragon fruit peel contained 5,30-10,60 $\mu \mathrm{g}$ oligosaccharides.

\section{A. Overrun}

Table 1 shows that low-fat ice cream with the substitution of super red dragon fruit peel on various levels of $0,6,8,10$ and $12 \%$ are significantly different $(\mathrm{P}<0,01)$ on overrun value. The substitution of dragon fruit peel into the ice cream mix increases the total solids. The viscosity of the ice cream mix will increase as the total solids increase.

According to [16], the thicker the ice cream mix causes the bigger surface tension so that the air will be difficult to penetrate to the surface of the ice cream mix and causes a poor development of the ice cream. The recommended standard of overrun value for household scale is $35-50 \%$, while for the industrial scale is 70-80\% [17]. The low overrun value in low-fat ice cream with the substitution of super red dragon fruit peel is also due to the substitution of carbohydrate-based fat replacer.

According to Crizel, et al. [2], carbohydrate-based fat replacer has the ability to increase the viscosity thereby decreasing the whipping capacity of the ice cream. Similar results were obtained by Adapa et al. [18] and Crizel, et al. [2] who found that the carbohydrate fat replacer mix had low overrun because of the higher viscous component, which could have prevented air incorporation.

\section{B. Melting Time}

Table 1 shows that low-fat ice cream with the substitution of super red dragon fruit peel on various levels of $0,6,8,10$ and $12 \%$ are significantly different $(\mathrm{P}<0,01)$ on melting time. The more the substitution of dragon fruit peel into the ice cream mix, the higher the melting time value.

According to Chauliyah [19], the melting time is affected by the total amount of solid material contained in the ice cream. Ice cream with higher viscosity will have greater resistance to melt down. 
TABEL I

MEAN VALUE OF OVERRUn, MELTING TIME, VISCOSITY AND COLOUR; L*A*B* OF LOW-FAT ICE CREAM With THe Substitution OF SUPER REd DRAGON Fruit PEEL

\begin{tabular}{|c|c|c|c|c|c|c|}
\hline \multirow{2}{*}{$\begin{array}{c}\text { Substitution } \\
\text { of Dragon } \\
\text { Fruit Peel } \\
(\%)\end{array}$} & Overrun (\%) & Melting Time & Viscosity (cP) & \multicolumn{4}{|c|}{ Colour Value } \\
\cline { 4 - 8 } & & & $L^{*}$ & $a^{*}$ & $b^{*}$ \\
\hline 0 & $81,66 \mathrm{a}$ & $7,00 \mathrm{a}$ & $117,29 \mathrm{a}$ & $82,84 \mathrm{a}$ & $-3,90 \mathrm{a}$ & $28,03 \mathrm{a}$ \\
\hline 6 & $53,39 \mathrm{~b}$ & $11,81 \mathrm{~b}$ & $268,38 \mathrm{~b}$ & $66,15 \mathrm{~b}$ & $10,92 \mathrm{~b}$ & $20,78 \mathrm{~b}$ \\
\hline 8 & $38,40 \mathrm{c}$ & $16,11 \mathrm{c}$ & $551,03 \mathrm{c}$ & $63,80 \mathrm{c}$ & $12,78 \mathrm{c}$ & $19,25 \mathrm{bc}$ \\
\hline 10 & $25,15 \mathrm{~d}$ & $21,43 \mathrm{~d}$ & $791,76 \mathrm{~d}$ & $61,35 \mathrm{~d}$ & $14,20 \mathrm{~d}$ & $18,56 \mathrm{bc}$ \\
\hline 12 & $15,08 \mathrm{e}$ & $24,48 \mathrm{e}$ & $1.499,04 \quad \mathrm{e}$ & $59,09 \mathrm{e}$ & $15,89 \mathrm{e}$ & $16,70 \mathrm{c}$ \\
\hline
\end{tabular}

Notes : Values which are followed by the same lowercase alphabet in the same column is not significantly different at level of 5\% according to DNMRT.

Melting time is also affected by the overrun value of the ice cream. The more solid materials added to the ice cream mix, the lower overrun value of the ice cream would be. Overrun value of the ice cream indicated the amount of air trapped in the ice cream system. Ice cream with the higher overrun value indicated the more amount of air trapped in the ice cream system, so that when the temperature of the environment changed the ice cream would melt faster than the ice cream with lower overrun value.

The results are in the same manner with Dewanti [20] whom find that the melting rate of an ice cream is also associated with the value of overrun. The higher the overrun value the faster the ice cream would melt, otherwise the lower the overrun value the slower the ice cream melt.

\section{Viscosity}

Table 1 shows that low-fat ice cream with the substitution of super red dragon fruit peel on various levels of $0,6,8,10$ and $12 \%$ are significantly different $(\mathrm{P}<0,01)$ on viscosity value. According to Marshall et al. [21] and Amal et al. [22], a certain level of viscosity is essential for proper whipping and retention of air cells in ice cream system.

The more the substitution of dragon fruit peel into the ice cream mix, the higher the viscosity value of the ice cream mix would be. This is due to the abilities of the carbohydrate-based fat replacer to form gel and increase water-holding capacity, so that can increase the viscosity of the ice cream mix. According to Adapa et al. [18], ice cream mixtures containing carbohydrate based fat replacers exhibit a viscous behavior because of their ability to absorb water, which in turn increases the viscosity of the system.

The results are in the same manner with Mahdian and Karzhian [23] whom find that the substitution of inulin as a carbohydrate-based fat replacer is significantly increase the viscosity of low-fat ice cream (5\% milk fat). Furthermore, El-Nagar et al. (2002) in Amal et al. [22] found that an increase in the viscosities of the low-fat samples containing carbohydrate-based fat replacer which can be explained by the interactions of the dietary fiber and liquid components of the ice cream mixture.

\section{D. $\operatorname{Colour}\left(L^{*} a^{*} b^{*}\right)$}

Table 1 shows that the substitution of super red dragon fruit peel is significantly different $(\mathrm{P}<0,01)$ on the value of colour lightness $\left(\mathrm{L}^{*}\right)$, mixed of chromatic red-green $\left(\mathrm{a}^{*}\right)$ and mixed of chromatic yellow-blue $\left(b^{*}\right)$ of the low-fat ice cream with the substitution of super red dragon fruit peel.

The $\mathrm{L}^{*}$ value is gradually decrease as the substitution of super red dragon fruit peel increase. This is because the increasing of the substitution of super red dragon fruit peel make the more intense colour of red-purple to the sample, so that the more lights would be absorbed into the sample and the ability of sample to reflect the lights would be decreased resulted in the decreasing of $\mathrm{L}^{*}$ value.

The $a^{*}$ value tends to increase as the substitution of super red dragon fruit peel increase. This is due to the increasing of the substitution of super red dragon fruit peel give the more intense reddish colour to the sample. The pigment that is responsible for the red-purple colour of dragon fruit is betalain compounds including betacyanin [24].

The value of $b^{*}$ tends to decrease as the substitution of super red dragon fruit peel increase. The colour of yellowish chromatic in low-fat ice cream came from the natural colour of milk which was used as the ingredients in the low-fat ice cream. Milk fat contains carotene which give the colour of yellowish to milk [17]. The value of $b^{*}$ is gradually decrease as the substitution of super red dragon fruit peel increase. This is due to the lack of carotene pigment from milk fat is covered by the dominated intense red-purple colour of the betacyanin pigment in low-fat ice cream with the substitution of super red dragon fruit peel.

\section{E. Organoleptic Evaluation}

1) Colour: Table 2 shows that the substitution of super red dragon fruit peel is significantly different $(\mathrm{P}<0,01)$ on the hedonic quality of colour of the low-fat ice cream with the substitution of super red dragon fruit peel. The mean value of hedonic quality of colour score of low-fat ice cream with the substitution of super red dragon fruit peel at the treatment of $0 \%$ to $12 \%$ is ranged between 1,00 (White) to 4,55 (Slightly Purplish Pink).

As the substitution of super red dragon fruit peel increase, the colour of low-fat ice cream with the substitution of super red dragon fruit peel is found to be more purplish rosy. The results are in the same manner with Waladi et al. [13] whom found that the increase of the substitution of red dragon fruit peel to the ice cream would increase the reddish colour to the ice cream. According to Elastri [25], super red dragon fruit peel has the pigment of betalain, a group of natural dies which will give the colour of red-purple. 
TABEL II

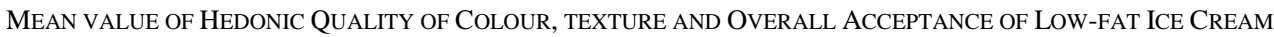
WITH THE SUBSTITUTION OF SUPER RED DRAGON FRUIT PEEL

\begin{tabular}{|c|c|c|c|}
\hline $\begin{array}{l}\text { Substitution of Dragon Fruit Peel } \\
\qquad(\%)\end{array}$ & Colour $^{1}$ & Texture $^{2}$ & $\begin{array}{c}\text { Overall } \\
\text { Acceptance }^{3}\end{array}$ \\
\hline 0 & $1,00 \mathrm{a}$ & $2,65 \mathrm{a}$ & $2,80 \mathrm{a}$ \\
\hline 6 & $2,70 \mathrm{~b}$ & $3,35 \mathrm{~b}$ & $3,55 \mathrm{~b}$ \\
\hline 8 & $3,10 \mathrm{c}$ & $4,15 \mathrm{c}$ & $4,45 \mathrm{c}$ \\
\hline 10 & 4,00 & $2,20 \quad \mathrm{~d}$ & $2,20 \quad \mathrm{~d}$ \\
\hline 12 & $4,55 \quad \mathrm{e}$ & $1,10 \quad \mathrm{e}$ & $1,50 \quad \mathrm{e}$ \\
\hline \multicolumn{4}{|c|}{ 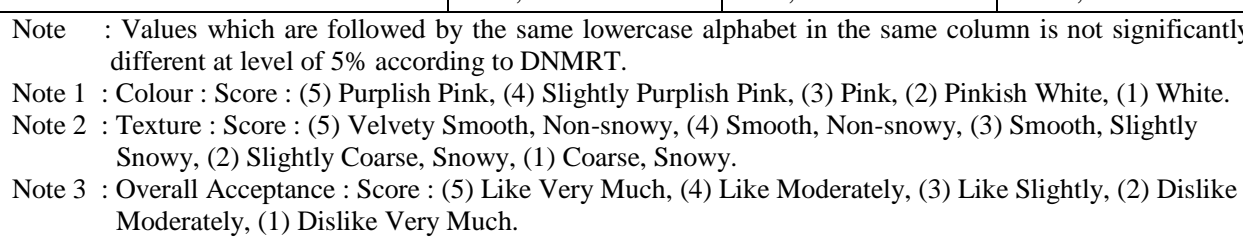 } \\
\hline
\end{tabular}

2) Texture: Table 2 shows that the substitution of super red dragon fruit peel is significantly different $(\mathrm{P}<0,01)$ on the hedonic quality of texture of low-fat ice cream with the substitution of super red dragon fruit peel. the mean value of hedonic quality of texture score of low-fat ice cream with the substitution of super red dragon fruit peel at the treatment of $0 \%$ to $12 \%$ is ranged between 1,10 (Coarse, Snowy) to 4,15 (Smooth, Non-snowy).

The score of hedonic quality of texture tends to increase as the substitution of super red dragon fruit peel increase from $0 \%$ to $8 \%$, then decrease gradually from the treatment of $10 \%$ to $12 \%$. Low-fat ice cream without the substitution of super red dragon fruit peel has the score of 2,65 (Slightly Coarse, Snowy). This is due to the lack of milk fat contain in the ice cream so that decreasing the total solids content in the ice cream, resulted in slightly coarse and snowy texture.

According to Potter and Hotchki (1995) in Puspitarini [17], milk fat will give the smooth texture in ice cream by minimizing the formation of ice crystals while freezing. The formation of large ice crystals and coarse texture is happened due to the lack of milk fat contain in the ice cream [20].

Meanwhile, low-fat ice cream with the substitution super red dragon fruit peel showed an increase score of hedonic quality of texture at the treatment of $6 \%$ to $8 \%$, then decrease at the treatment $10 \%$ to $12 \%$. The substitution of $8 \%$ super red dragon fruit peel has obtained a smoother texture of low-fat ice cream than the control low-fat ice cream. This is due to the increasing of solid material in the low-fat ice cream. As the percentage of solid material increase in the low-fat ice cream mix, the percentage of water content in the low-fat ice cream decrease and resulted in a fewer formation of ice crystals while freezing.

Nevertheless, too much percentage of solid material in the low-fat ice cream mix would make the mixes too viscous and resulted in a coarse and snowy texture of low-fat ice cream. This is due to the too viscous mix decrease the whipping ability of the low-fat ice cream, so that the overrun value would decrease and result a very solid and coarse lowfat ice cream as shown in low-fat ice cream with the substitution of $10 \%$ and $12 \%$ super red dragon fruit peel.

According to Dewanti [20], the substitution of carbohydrate ingredients would result a more solid ice cream texture. Carbohydrate-based ingredients have hydroxyl group that has the ability to absorb water. The ability to absorb water is related to its ability to form gel, the more water trapped in the gel structure causes a higher viscosity. As the viscosity become higher, the ice cream would result a more solid and hard texture [26].

3) Overall Acceptance: Table 2 shows that the substitution of super red dragon fruit peel is significantly different $(\mathrm{P}<0,01)$ on the overall acceptance of low-fat ice cream with the substitution of super red dragon fruit peel. the mean value of overall acceptance score of super red dragon fruit peel at the treatment of $0 \%$ to $12 \%$ is ranged between 1,50 (Dislike Very Much) to 4,45 (Like Moderately).

Overall acceptance of low-fat ice cream with the substitution of super red dragon fruit peel is well affected by its hedonic quality of texture. This is because the texture is an important attribute and affects the overall acceptance of ice cream to consumer, where the desired ice cream has soft and smooth feels in the mouth when it is being consume.

According to Clark, et al. [27], texture is an important part of ice cream and as an indicator of good quality ice cream. The texture of an ice cream can be evaluated by the touches of the tongue directly while consuming the ice cream. Proper ice cream has soft and smooth texture and has good palatability inside the mouth.

TABEL III

MEAN VALUE OF PAIRED COMPARISON EVALUATION OF LOW-FAT ICE CREAM WITH THE SUBSTITUTION OF SUPER RED DRAGON FRUIT PEEL

\begin{tabular}{|l|c|}
\hline \multicolumn{1}{|c|}{ Ice Cream Sample } & Similarity \\
\hline $\begin{array}{l}\text { Low-Fat Ice Cream with The } \\
\text { Substitution of Super Red Dragon } \\
\text { Fruit Peel 8\% }\end{array}$ & 0,20 \\
\hline Commercial Ice Cream (P) & 0,20 \\
\hline
\end{tabular}

Note : Values which are followed by the same lowercase alphabet in the same column is not significantly different at level of 5\% according to DNMRT.

Note: Paired Comparison: Score : (1) Dissimilar, (0) Similar. 
4) Paired Comparison: Organoleptic evaluation of paired comparison was done by comparing the texture of best treatment of low-fat ice cream with the substitution of super red dragon fruit peel and the commercial ice cream. Aice Milk was the choosen commercial ice cream as the comparison sample $(\mathrm{P})$.

This evaluation is aimed to know whether the low-fat ice cream with the substitution of super red dragon fruit peel can be as acceptable as the commercial ice cream by the consumers. Table 3 shows that the texture of the low-fat ice cream with the substitution of super red dragon fruit peel and the commercial ice cream is not significantly different. the mean value of paired comparison score of low-fat ice cream with the substitution of super red dragon fruit peel and commercial ice cream $(\mathrm{P})$ is equal with the value of 0,20 (Similar).

This indicates that low-fat ice-cream with the substitution of super red dragon fruit peel at the proper treatment of $8 \%$ has the similar texture with the commercial ice cream $(\mathrm{P})$ which is used as the comparison sample. Thus, it can be concluded that the texture of low-fat ice cream with the substitution of $8 \%$ super red dragon fruit peel is already as acceptable as the commercial ice cream $(\mathrm{P})$ by the consumer.

This is due to the substitution of $8 \%$ super red dragon fruit peel as the carbohydrate-based fat replacer in low-fat ice cream is properly able to replace some part of milk fat which is reduced from low-fat ice cream. Carbohydrate-based fat replacers have diverse functional properties that mimic some of the characteristic physiochemical attributes and desirable eating qualities of fat, viscosity, mouthfeel and appearance [28].

\section{CONCLUSIONS}

Based on the results of this research, it can be concluded that; The substitution of super red dragon fruit peel is significantly different $(\mathrm{P}<0,01)$ on the value of overrun, melting time, viscosity, colour; lightness $\left(L^{*}\right)$, red-green chromatic $\left(a^{*}\right)$ and yellow-blue chromatic $\left(b^{*}\right)$, hedonic quality of colour, hedonic quality of texture and overall acceptance.

The best formulation of low-fat ice cream with the substitution of super red dragon fruit peel is found at the treatment of $8 \%$ with the value of overrun $38,40 \%$, melting time of 16,11 minutes, viscosity of $551,03 \mathrm{cP}$, colour; lightness $\left(L^{*}\right)$ of 63,80 , red-green chromatic $\left(a^{*}\right)$ of 12,78 and yellow-blue chromatic $\left(b^{*}\right)$ of 19,25 , hedonic quality of colour of 3,10 (Pink), hedonic quality of texture of 4,15 (Smooth, Non-snowy) and overall acceptance of 4,45.

The best formulation of low-fat ice cream with the substitution of $8 \%$ super red dragon fruit peel was not significantly different on the paired comparison evaluation with the score of 0,20 (Similar).

\section{REFERENCES}

[1] Salem, S. A., Hamad, E. M. and Ashoush, I. S. 2016. Effect of Partial Fat Replacement by Whey Protein, Oat, Wheat Germ and Modified Starch on Sensory Properties, Viscosity and Antioxidant Activity of Reduced Fat Ice Cream. Journal of Food and Nutrition Sciences 7: 397-404. Scientific Research Publishing Inc.

[2] Crizel, T. D. M., Araujo, R. R. D., Rios, A. D. O., Rech, R. and Flores, S. H. 2014. Journal of Food Science and Technology. Campinas 34(2): 332-340. ISSN 0101-2061.
[3] Masyukuri. 2002. Technology of Making an Ic Cream. Module of Lecture Material. Faculty of Livestock. University of Diponegoro, Semarang.

[4] Guven, M., Yas-ar, K., Karaca, O. B. and Hayaloglu, A.A. 2005. The Effect of Inulin as a Fat Replacer on the Quality of Set-Type LowLow Yogurt Manufacture. International Journal of Dairy Technology, $58,180-184$.

[5] Goff, H. D. and Hartel, R. W. 2013. Ice Cream Seventh Edition. Springer. New York Heidelberg Dordrecht London.

[6] Wu, L. C., Hsu, H. W., Chen, Y. C., Chiu, C. C., Lin, Y. I. and Ho, J. A. 2005. Antioxidant and Antiproliferative Activities of Red Pitaya. Journal of Food Chemistry. Department of Applied Chemistry. National Chi-Nan University, No. 1 University Road, Puli, Nantou, 545 Taiswan.

[7] Saneto, B. 2005. Characterization of Red Dragon Fruit Peel ( $H$. polyrhizus). Journal. Major of Technology of Agricultural Product, Faculty of Agriculture. University of Widyagama Malang.

[8] Jaafar, R. A., Rahman, A. R. B. A., Mahmod, N. Z. C. and Vasudevan, C. 2009. Proximate Analysis of Dragon Fruit (Hylecereus polyhizus). American Journal of Applied Science. Science Publication. ISSN 1546-9239.

[9] Dwiyani, R. K. 2008. Physical and Chemical Characteristic of Sinbiotic Yogurt Ice Cream During Storage. Undergraduate Thesis. Study Program of Technology of Livestock Product, Faculty of Livestock. Bogor Agricultural Institute, Bogor.

[10] Bourne, M. C. 2002. Food Texture and Viscosity 2nd Edition: Concept and Measurement. Elsevier Science and Technology Books. ISBN : 0121190625.

[11] Andarwulan, N., Kusnandar, F. and Herawati, D. 2011. Analysis of Food. Dian Rakyat. Jakarta.

[12] Setyaningsih D, Apriyantono A, Puspita M. 2010. Analysis of Sensory for Food and Agro Industry. IPB Press, Bogor.

[13] Waladi, Johan, V. S. and Hamzah, F. 2015. Utilization of Red Dragon Fruit Peel (Hylocereus polyrhizus.) as The Additive in The Making of Ice Cream. Journal of Faperta Vol. 2 No. 1. Study Program of Technology of Agricultural Product, Major of Agricultural Technology, Facultas of Agriculture. University of Riau.

[14] Romadani, D. 2016. Effect of Combination of Soybean and Pineapple Extract to The Physical, Chemical and Organoleptic Characteristic of Vegetal Ice Cream. Undergraduate Thesis. Major of Technology of Agricultural Product, Faculty of Agricultural Technology, University of Jambi, Jambi.

[15] Khalili, R. M. A., A. H. Norhayati, M. Y. Rokiah, R. Asmah, M. T. Mohd Nasir and Siti Muskinah. 2006. Proximate Composition and Selected Mineral Determination in Originically Grown Red Ptaya (Hylocereus sp.). Journal of Tropical Agricultural Food Science.

[16] Muse, M. R. and Hartel, R. W. 2004. Ice Cream Structural Elements that Affect Melting Rate and Hardness. Journal of Dairy Science. 87:1-10.

[17] Puspitarini, R. 2012. The Content of Fiber, Fat, Physical Characteristic and Acceptance of Ice Cream with The Addition of Various Types of Rice and Sticky Rice. Undergraduate Thesis. Study Program of Science of Nutrition, Faculty of Medical, University of Diponegoro, Semarang.

[18] Adapa, S., Dingeldein, H., Schmidt, K. A. and Herald, T. J. 2000. Rheological Properties of Ice Cream Mixes and Frozen Ice Creams Containing Fat and Fat Replacers. Journal of Dairy Science. Dept. of Animal Sciences and Industry. Kansas State University, Manhattan 66506.

[19] Chauliyah, A. I. N. 2015. Analysis of Nutrition Content and Antioxidant Activity of Honey Pineapple Ice Cream. Undergraduate Thesis. Study Program of Science of Nutrition. Faculty of Medical. University of Diponegoro. Semarang.

[20] Dewanti, F. K. 2013. Subtitution of Inulin of Gembili Bulbs (Dioscorea esculenta) in Ice Cream Product as an Alternative Food Product of High Fiber and Low Fat. Undergraduate Thesis. Study Program of Science of Nutrition. Faculty of Medical, University of Diponegoro. Semarang.

[21] Marshall, R. T., Goff, H. D., and Hartel, R. W. 2003. Ice Cream 6th Edition. Kluwer Academic Publishers. New York.

[22] Amal, M. H., Haleem, A. and Awad, R. A. 2015. Some Quality Attributes of Low Fat Ice Cream Subtituted with Hullness Barley Flour and Barley B-glucan. Journal of Food Science and Technology. 52(10):6425-6434.

[23] Mahdian, E. and Karazhian, R. 2013. Effects of Fat Replacers and Stabilizers on Rheological, Physicochemical and Sensory Properties 
of Reduced-fat Ice Cream. Journal of Agricultural Science and Technology. 15:1163-1174.

[24] Nurul, S. R. and Asmah, R. 2014. Variability in Nutritional Composition and Phytochemical Properties of Red Pitaya (Hylocereus polyrhizus) from Malaysia and Australia. International Food Research Journal 21(4): 1689-1697.

[25] Elastri, A. 2015. Effect of Red Dragon Fruit Peel Extract to The Quality of Ice Cream. Undergraduate Thesis. Major of Family Welfare. Faculty of Engineering. University of Negeri Padang. West Sumatera.
[26] Barclay, T., Markovic, M. G., Cooper, P. and Petrovsky, N. 2010. Inulin - a Versatile Polysaccharide with Multiple Pharmaceutical and Food Chemical Uses. Journal of Excipients and Food Chemicals.

[27] Clark, S., Michael, C., Drake, M. A. and Bodyfelt, F. 2009. The Sensory Evaluation of Dairy Product $2^{\text {nd }}$ Edition. New York: Springer.

[28] Ognean, C. F., Darie, N. and Ognean, M. 2006. Fat Replacers Review. Journal of Agroalimentary Processes and Technologies, Vol. XII, No. 2, 433-442. Faculty of Agricultural Sciences. University of Sibiu, Romania. 